Purdue University

Purdue e-Pubs

Purdue CIBER Working Papers

Krannert Graduate School of Management

$1-1-1998$

\title{
International Integration and Growth: a Survey and Empirical Investigation
}

Jon D. Haveman

Public Policy Institute of California

V. Lei

Purdue University

J.S. Netz

Purdue University

Follow this and additional works at: http://docs.lib.purdue.edu/ciberwp

Haveman, Jon D.; Lei, V.; and Netz, J. S., "International Integration and Growth: a Survey and Empirical Investigation" (1998). Purdue CIBER Working Papers. Paper 131.

http://docs.lib.purdue.edu/ciberwp/131

This document has been made available through Purdue e-Pubs, a service of the Purdue University Libraries. Please contact epubs@purdue.edu for additional information. 


\title{
International Integration and Growth: A Survey and Empirical Investigation
}

\author{
Jon D. Haveman \\ Purdue University \\ Vivian Lei \\ Purdue University \\ Janet S. Netz \\ Purdue University
}

98-003

\footnotetext{
Center for International Business Education and Research Purdue University

Krannert Graduate School of Management 1310 Krannert Building

West Lafayette, IN 47907-1310

Phone: (765) 494-4463

FAX: (765) 494-9658
} 


\title{
INTERNATIONAL INTEGRATION AND GROWTH: A SURVEY AND EMPIRICAL INVESTIGATION
}

\author{
Jon D. Haveman, Vivian Lei, and Janet S. Netz \\ Purdue University
}

August 1998

\begin{abstract}
Endogenous growth theory suggests that increased international interactions can lead to increased growth. Growth may be stimulated through a variety of means: trade and/or direct investment may act as a means of technology diffusion; increased imports may reduce competitive distortions in the domestic economy; reduced barriers to trade may create a larger market and hence a higher return to innovation, encouraging higher investment in $R \& D$ activities; reduced barriers to trade may lead to rationalization of the $R \& D$ sector. Empirical work has confirmed that openness and FDI are positively correlated with growth. Little empirical work on the influence of trade blocs on growth has occurred; results are mixed. Notably, empirical work has typically focused on a single avenue of international integration - trade, FDI, or regional integration - rather than taking a comprehensive approach. The problem with a piecemeal approach is that variables measuring international interactions are highly correlated, not only with each other but with other regressors commonly included in growth equations. Thus focusing on one form of international integration while omitting the other forms is likely to result in a biased estimate of the impact of the variable of interest.

After surveying the theoretical and empirical work, we attempt a comprehensive assessment of different forms of international integration on growth. In particular, we consider the impact of trade, of inward foreign direct investment, of preferential treatment of less developed countries, and of membership in trade blocs. Our results confirm that general openness and foreign direct investment into a country do lead to increased growth; that special treatment by the European Union of former colonies statistically insignificantly increases growth; that membership in a trade bloc facilitates growth; and that the size of the trade bloc to which a country belongs and the variation in income in the trade bloc also encourage more rapid growth among member countries. We also find that omission any of these international sources of growth biases the coefficients estimated on included regressors.
\end{abstract}

Keywords: Growth, trade barriers, trade blocs, FDI

JEL Classification: F15, F43

\begin{abstract}
Acknowledgments: We thank Deng-Shing Huang, David Cook, and Henry Wan for useful comments, as well as audience members at the Dynamics, Economic Growth, and International Trade, III conference in Taipei, Taiwan, August 1998. Funding from Purdue University's Center for Internationa Business Education and Research is gratefully acknowledged.
\end{abstract}

Address: Department of Economics, Purdue University, W. Lafayette, IN 47907-1310

Phone: Haveman: (765) 494-6156; Lei: (765) 494-4505; Netz: (765) 494-4452; Fax: (765) 494-9658

E-mail: jon@haveman.org; wenchieh_lei@mgmt.purdue.edu; netz@purdue.edu 


\title{
INTERNATIONAL INTEGRATION AND GROWTH: A SURVEY AND EMPIRICAL INVESTIGATION
}

\author{
Jon D. Haveman, Vivian Lei, and Janet S. Netz
}

\section{Introduction}

In recent years there has been a renewed interest in studying the determinants of growth given the divergence in per capita incomes across the nations of the world. Neoclassical growth theory, as formalized by Solow (1956) and Swan (1956), predicts that all countries will converge to the same steady-state growth rate. Given that this prediction does not square with the observed divergence in growth rates, others have developed theories explaining growth without the troubling convergence prediction. ${ }^{1}$ While endogenous growth theories consider a variety of mechanisms by which growth can be sustained, we concentrate on how international interactions contribute to growth. ${ }^{2}$ We are interested in international integration, generally, including trade, foreign direct investment, and the formation of trade blocs.

We begin by briefly illustrating the theoretical work and surveying the empirical work that directly relates international integration to growth. ${ }^{3}$ We empirically analyze the effects of different types of international interactions on growth. Our paper contributes to the literature by discriminating between the different channels through which growth has been affected by international integration as well as by integrating the several channels through which international interactions may influence growth. Most, if not all, empirical

${ }^{1}$. See the symposium on growth theory in the Journal of Economic Perspectives, 1994, for an overview of the development of the theory.

2 We use the term international integration to broadly refer to any type of international interaction. In particular, we are not limiting the discussion to the formation of trade blocs, though we include trade blocs as one type of international interaction in which we are interested.

3 Long and Wong, 1997, provide a theoretical framework which can capture most endogenous growth theories. They then apply the framework to capture the theoretically suggested effects of trade on growth. Walz, 1997 a, surveys the theoretical work on the effect of international integration, including trade, on growth. To our knowledge, no comprehensive survey of the empirical effects of international interactions, including trade, foreign direct investment, and preferential trading arrangements, has been written. 
work focuses on one international interaction at a time. Because measures of international interactions are highly and statistically significantly correlated, omitting any of them will lead to a biased estimate of the influence of those that are included in the regression.

In general, we do find that increased international integration does lead to faster growth. In particular, increases in inward FDI, increases in the trade share of GDP, increases in exports to richer countries, being a member of a trade bloc, increases in the aggregate size of the other members of the trade bloc, and increases in the dispersion of income of trade bloc members lead to increased growth. Two puzzles emerge. The more home bias a country demonstrates and the more imports from rich countries, the lower the growth rate.

\section{Theoretical Predictions}

In this section we discuss some of the ways in which endogenous growth theory and trade theory have come together to highlight the mechanisms by which international interactions can influence growth. Trade theory shows that countries gain from trade, in the sense of achieving higher income, by reallocating scarce resources to those sectors in which a country has a comparative advantage. ${ }^{4}$ Endogenous growth theory attempts to explain growth while endogenizing technological change. When integrated, the two theories shed light on how trade, trade policy, and investment affect growth. We highlight here endogenous growth models of open economies. The papers incorporate the insights of both bodies of literature: growth may be sustained by dynamic comparative advantage, ${ }^{5}$ technology diffusion, ${ }^{6}$ learning-by-doing, spillovers, ${ }^{7}$ and economies of scale. Several survey papers focusing on theoretical work on growth that incorporates international interactions have been

4 Baldwin, 1992b, shows that changes in trade policy affect the accumulation of factors of production, in particular human and physical capital, and thus can affect growth rates.

5 Standard trade theory, since static, shows only that trade can increase the level of a country's income. Dynamic comparative advantage refers to the reallocation of resources towards industries that exhibit spillovers of some sort (typically the R\&D industry), in which case resource reallocation can lead to a change in the growth rate as well as in the level of income. See Grossman and Helpman, 1991a chapter 9 and 1994, for a discussion of dynamic comparative advantage.

6 Keller, 1997, finds strong empirical evidence that trade leads to technology diffusion.

7 Coe, Helpman, and Hoffmaister, 1997, find empirical evidence that R\&D spillovers from industrial countries to developing countries are substantial. 
written, including those cited in footnote 3 . Therefore, we limit the discussion to several papers that provide examples of the ways in which international interactions may influence growth rather than surveying the vast literature on the topic.

Grossman and Helpman (1991a) discuss three channels, in addition to dynamic comparative advantage, through which international integration might affect a country's growth rate. First, international integration increases the opportunities for communication and thus facilitates the transmission of technology. Second, increasing international competition can encourage entrepreneurs to engage in more $R \& D$ activities, while at the same time reducing duplication of research effort. Finally, the size of the market is expanded with freer trade, potentially increasing investment activity. Grossman and Helpman (1991b) develop a dynamic general equilibrium model to discuss the knowledge spillovers through which trade improves a country's growth performance. A homogeneous, traded final good is produced by perfectly competitive firms using labor and non-traded, horizontally differentiated intermediate goods that require $R \& D$ to produce new varieties. Productivity of $R \& D$ is linked to the stock of knowledge capital, which depends not only upon domestic efforts on product development, but also upon the number of contacts that local firms have with the international research and business communities. The number of contacts is assumed to be positively related to the extent of international trade in commercial commodities. Thus, trade, and trade policies, can affect a country's growth. ${ }^{8}$

In their model, the effect of trade policy on the long-run growth rate depends on parameters in the production function. For example, in the case where the relative importance of spillover effects from international trade declines over time, trade policy can only influence the rate of knowledge accumulation and growth in the transition period. A policy such as a tariff, imposed by either the home or the foreign government, can reduce the chance of interacting with foreign firms, so that growth will slow during the transition period towards the steady state. However, in the long run, the volume of trade (and hence trade policy) has

8 Walz, 1997b, develops a model based on Grossman and Helpman, 1991, but incorporating foreign direct investment as the mean by which technology is diffused. He shows that countries more open to FDI have higher growth rates. 
no effect on the steady-state growth rate. On the other hand, in the case where the volume of trade grows at the same rate as the number of varieties of the differentiated industrial products, Grossman and Helpman prove that a reduction in the size of trade barriers will increase the ratio of the cumulative volume of trade relative to the number of varieties in the long run; this accelerates technological progress and therefore leads to a higher growth rate in the steady state. Thus, where trade and trade barriers do have an effect on growth, more international interactions (higher trade volumes, lower trade barriers) increase growth.

Ben-David and Loewy $(1997,1998)$ also suggest that trade may lead to economic growth by facilitating the diffusion of knowledge and knowledge accumulation among countries. They assume that the extent of knowledge spillovers between two countries is an increasing function of the volume of trade between them. As predicted by Grossman and Helpman, Ben-David and Loewy show that a unilateral tariff reduction by a single country would cause all trading countries to grow faster in the steady-state. In addition, Ben-David and Loewy show that removing or reducing tariffs improves growth by directly changing market clearing prices and thus consumption. Consequently, trade policy has an indirect effect on the extent of knowledge spillovers and accumulation.

Another mechanism through which international integration can contribute to growth, other than the knowledge spillover effect, is illustrated by Rivera-Batiz and Romer (1991). ${ }^{9}$ They emphasize the pure scale effect through which integration by two similar countries affects long-run growth. ${ }^{10}$ They distinguish two types of R\&D in which innovation occurs to differentiated capital inputs: a knowledge-driven specification and a lab equipment specification. The first type of $R \& D$ is characterized by the assumption that the $R \& D$ sector uses human capital and the existing stock of knowledge as inputs. Unskilled labor and physical capital, which also enter the production function of the manufacturing sector, have no impact on the accumulation of knowledge. In the lab equipment specification, $R \& D$ is assumed

9 Peretto, 1996, builds an alternative model of integration that supports the general insights of Rivera-Batiz and Romer.

10 Rivera-Batiz and Romer focus on similar countries in order to isolate the effect of economies of scale from the effect of gains arising from comparative advantage. 
to use the same inputs as the manufacturing product and knowledge per se has no value.

Complete integration can raise the growth rate and improve welfare in both countries, regardless of whether $R \& D$ per se has production value. However, for partial integration, Rivera-Batiz and Romer show that trade in goods alone without exchanging ideas has no effect on the long-run growth rate for both countries in the knowledge-driven R\&D model. The intuition behind this finding is straightforward. Without exchanging ideas, the stock of knowledge in both countries remains the same, and there will be no technological progress in either of these countries. Therefore, international trade can only have a level effect on the steady state without affecting the growth performance of a country. On the other hand, since trade in goods has already provided an incentive for researchers in different countries to specialize in different designs, allowing trade in ideas can take advantage of the fact that the worldwide stock of knowledge is twice as large as the stock in each individual country, and hence the productivity of human capital in the research sector and the growth rate of output can be increased. ${ }^{11}$

Rivera-Batiz and Romer conclude that it is not knowledge spillovers that cause the fundamental of long-run growth, but rather it is the increasing returns to scale, arising from the enlarged market size, in the production of new designs that result in a higher growth rate for two identical, integrated countries. Given that the production function of new designs exhibits increasing returns to scale, trade in goods can therefore provide the incentive to avoid redundant effort from operating two research sectors in isolation. Additionally, trade in ideas along communications networks in the knowledge-driven model and trade in capital goods in the lab equipment model can serve the function that ideas discovered in one country can be available for use in research in both countries.

Although Rivera-Batiz and Romer show that trading commodities alone between two similar countries can have no growth effect in the knowledge-driven model, it can also be

\footnotetext{
11 With the above predictions, however, we should not conclude that trade in goods can only have level effects and that trade in ideas raises the growth rate in the long run. For example, in the lab equipment model, flows in goods alone can have both level and growth effects by causing a higher interest rate and a higher savings rate.
} 
shown that this equilibrium is not stable in the case where two countries slightly differ in the initial stock of knowledge. Devereux and Lapham (1994) adopt the same type of model and prove that the symmetric balanced growth path can never be attained as long as the initial stocks of knowledge are not identical across two countries. ${ }^{12}$ Specifically, trading goods alone without exchanging ideas will eventually cause a country with a relatively small share in the initial world stock of designs to specialize in producing manufacturing goods and a country with a larger share to diversify between manufacturing and R\&D. These findings by Devereux and Lapham reinforce the importance of trade in commodities and the role played by comparative advantage in the process of income growth when two countries integrate with each other.

We thus see a variety of ways in which international interactions can affect growth. What hypotheses can we take from these stylized models to the "real" world? Since one role international interactions play is to diffuse technology, increased trade and increased foreign direct investment should increase growth. Rivera-Batiz and Romer's model also suggests that the establishment of a trade bloc, and the degree of integration attained within the trade bloc, could, in addition to contributing to technology diffusion, cause rationalization to occur in the $R \& D$ sectors, also leading to higher growth.

\section{Empirical Literature}

We now survey the empirical literature relating international integration to growth. Edwards (1993) provides a useful survey of empirical studies that largely predate the development of the new endogenous growth models. This work generally focuses on developing countries and the age-old question of whether a country should develop via export promotion or import substitution. The modern empirical literature has stepped away from developing countries to examine linkages between international interactions and growth. As discussed above, there are many avenues through which international interactions can affect growth

12 Walz, 1998, considers the effect of an enlargement of a common market to a third, technologically lagging, country, and finds that enlargement leads to increased growth for all members. Growth in the original members is spurred because they can reallocate resources towards their dynamic sector. 
in a country or set of countries. Unfortunately, the majority of empirical work has typically been narrow in focus, addressing only a single issue rather than all of the possible interactions that may lead to growth. Accordingly, we divide this section into three subsections: trade and openness, foreign direct investment, and preferential trading arrangements.

\section{Trade and Openness}

Perhaps the most empirically studied issue relating to growth and international interactions is trade and openness. The most commonly used variables have been the share of exports in GDP (or growth of exports) or the share of exports and imports in GDP. ${ }^{13}$ Openness is a catchall for the transmission of growth facilitators into a country. That is, the more a country trades, relative to its size, the more likely it is to experience the benefits of international interactions. ${ }^{14}$ To the extent that this raw measure is capable of capturing the complicated issues raised by the new growth theories, this is a reasonable approach. These studies typically find a positive relationship between the trade share and growth. Criticisms of these studies include the robustness of the results, the identical treatment of imports and exports, and the endogeneity of trade flows or their correlation with other pro-growth policies.

Because export and trade shares may not capture the degree to which a country is "open," given that trade volume is determined by a number of characteristics beyond trade policy, many studies have examined measures of the degree to which a country is open. ${ }^{15}$ In one of the most comprehensive treatments of the issue of openness, Harrison (1996) considers a number of more specific measures of openness over a sample of developing countries. Her openness indicators include: an annual index of trade liberalization based on exchange rate

\footnotetext{
13 For example, Feder, 1983, and Kormendi and Mequire, 1985, use measures of exports, while Sinha and Sinha, 1996, and Harrison, 1996, use measures of total trade share. Edwards, 1993, surveys cross-sectional studies of the effects of exports on growth. Levine and Renelt, 1992, note that similar results obtain with both measures.

14 Recall that several models suggest that the higher the number of transactions with foreigners, the more transmission of technology, and hence the more growth, occurs.

15 Coe and Helpman, 1995, present a model of R\&D spillovers in which a country benefits for foreign R\&D activity the more open is the country.
} 
and commercial policies (from Papageorgiou, Michaely, and Choksi, 1991); another based on tariffs and non-tariff barriers (from Thomas, Halevi, and Stanton, 1991); the black-market premium; the share of trade in GDP (the usual openness measure); movements toward international prices; a modified version of the price distortion index used in Dollar (1991); the indirect bias against agriculture from industrial sector protection; and the overvaluation of the exchange rate. Generally speaking, the results show movements toward openness positively affect growth, while greater distortions reduce economic growth. Edwards (1992) instead adopts indices of openness and intervention in trade based on Leamer's (1988) approach to predicting trade. ${ }^{16}$ In essence, the openness and intervention indices are based on deviations of observed trade flows and trade intensities from their predicted value. He too finds broad support that more openness leads to higher growth rates on a sample of developing countries. Wolf (1993) develops an index of openness based on the difference between actual trade and trade levels predicted by a factor endowments model of trade. He also finds that openness leads to higher growth rates. ${ }^{17}$

Frankel and Romer (1996) focus on the potential endogeneity of the trade share and other more direct measures of openness, such as trade barriers. They note that countries with liberal international trade policies are likely to be those with domestic policies that are also conducive to growth. In this case, measures of the policy stance and trade volumes may reflect variables omitted from the income equation rather than the effects of international trade. Their approach is to instrument for trade using the geographic component of a countries trade from a common gravity equation; they rightly point out that geographic isolation is unlikely to influence a country's income other than by reducing its interactions with other countries. They continue to find a significant impact of trade on growth, and suggest that studies that do not account for endogeneity understate the magnitude of the

16 Harrison, 1996, and Pritchett, 1991, note that Leamer's openness measure is inversely related to other measures of openness, a troubling result. Levine and Renelt note that Leamer's openness index is positively related to his distortions index. It is thus not clear what Leamer's indices are measuring.

17 Others who consider alternative measures include: Fischer, 1993, includes black market premium; Knight, Loayza, and Villanueva, 1993, include measures of outward-oriented trade policies; and Lee, 1993, looks at tariff rates and black market premia. In general, these studies also find support for the idea that countries that are more open grow faster. 
effect. ${ }^{18,19}$ Van den Berg (1996) tackles the simultaneity issue by adopting a time series approach to simultaneously estimating growth, export share, import share, and investment share for a variety of Latin American countries. When significant, the effect of export and import share is positive; when both are significant for a country, the effect of exports is generally of larger magnitude than the effect of imports.

Levine and Renelt (1992) find that the common favorable relationship between trade and growth is not robust to changes in the broader model specification. They consider the robustness of export share, import share, Leamer's indices of openness and of distortions, the black market premium, and Dollar's index of real-exchange rate distortion. Under an extreme bounds test for robustness, they reject robustness for all measures. ${ }^{20}$ Levine and Renelt's robustness criteria is severe, prompting Sala-i-Martin (1997) to consider a more relaxed definition of robustness. He finds that trade share is not robust, but also finds that an alternative measure of openness, "Number of Years an Economy Has Been Open Between 1950 and 1990," is robustly positive and significant. In addition, Roubini and Sala-i-Martin (1991) note that Levine and Renelt allow the sample to change as different variables are included in the model. (The sample changes due to different missing values for different regressors.) Hence, while the coefficient on an openness variable may become insignificant when another variable is added to the specification, it is unclear whether the insignificance arises from the new specification or the new estimating sample. We limit our analysis to the same set of observations for all model specifications in order to avoid this problem.

\section{Foreign Direct Investment}

The role of FDI in the growth process has long been a topic of intense debate. Until relatively recently, however, there has been very little empirical analysis of the issue. The

\footnotetext{
18 Their approach of course does not allow them to address the issue of trade policy.

19 Several studies in the development literature consider the issue of endogeneity of exports. See, for example, Lee and Cole, 1994, who also find that the effect of trade is understated when endogeneity is present.

20 In particular, when they include investment share in the regressions, openness is not robustly related to growth. Therefore, they suggest that investment is the channel through which trade influences growth or convergence.
} 
recent developments in the growth theory, discussed above, have provided a convenient framework in which to pursue empirical work. Accordingly, the evidence of the impact of FDI on growth is expanding rapidly. To date, however, the evidence is not clear; there is evidence of both a positive and a negative impact of FDI on growth in developing and developed countries.

Borensztein, DeGregorio, and Lee (1995) present compelling results of the impact of FDI from industrial countries to 69 developing countries. They find that FDI contributes to growth in less developed countries primarily through technology transfer. Foreign investment is found to contribute relatively more to growth than domestic investment, presumably by implementing technologies with higher productivity. They suggest an important caveat, however, that a host country will only benefit in this way once it obtains a minimum threshold stock of human capital. In essence, without the resources necessary to exploit the new technology on a wide scale, these productivity improvements will not be realized. A secondary finding is that foreign investment and domestic investment are complements. That is, one dollar of foreign investment results in more than a one dollar increase in the level of investment in the economy. This result suggests a significant complementarity effect between foreign-owned production and domestically-owned firms.

Balasubramanyam, Salisu, and Sapsford (1996) test the hypothesis that trade and inward FDI are complements for 46 developing countries. This is accomplished by dividing the sample into countries pursuing an outward-oriented trade regime and those pursuing import substitution policies. They find that FDI is more likely to be a contributor to growth in countries pursuing outward-oriented (export promoting) policies, and that in fact there is evidence that FDI is negatively related to growth in countries pursuing import substitution policies. A shortcoming of the conclusion centers around the distinct possibility that the nature of the foreign direct investment may differ significantly in each case. In the case of outward-oriented countries, the investment may well represent an the appropriate specialization and utilization of abundant resources in the host country. FDI into countries 
pursuing import-substituting strategies, on the other hand, may represent efforts to jump trade barriers. As such, this investment may embody technologies that are inappropriate for the host country, resulting in an inefficient use of domestic resources. In addition, the model does not include a measure of imports. If FDI is an effort to hurdle trade barriers, then FDI and imports will be negatively correlated, and the included FDI measure will pick up both the effect of FDI as well as the effect of imports. This too may explain the observed negative coefficient, since high FDI may also proxy for low imports, negatively affecting growth. ${ }^{21}$ Tsai (1994) considers the determinants of FDI as well as the impact of FDI on growth, and finds that the positive impact of FDI, as commonly found in the absence of controlling for the determinants of FDI, may be overstated. Saltz (1992) finds a negative relationship between FDI and growth. The paper provides evidence of a negative relationship between FDI and growth in third world countries, pointing to overly capital-intensive technologies, monopolization and transfer pricing distortions resulting in the underutilization of labor. He also suggests that direct investment may well cause more outflow of capital over time than portfolio investment. ${ }^{22}$

Much of the work on the effect of FDI on growth has concentrated on FDI from developed countries into developing countries, and the results have been mixed. If Saltz is correct that investment by developed countries embodies technology that is inappropriate for developing countries, it suggests that FDI by similar countries may increase growth. We therefore include FDI from all countries.

\section{Preferential Trading Arrangements}

An aspect of trade regimes that remains under-studied is that of preferential trading arrangements: preferential market access or formal bilateral agreements. In particular, the Generalized System of Preferences (GSP) is often defended by the notion that granting

21 It is this type of bias that we hope to eliminate by adopting a comprehensive approach to measuring the effects of international interactions on growth.

22 Saltz also does not control for the influence of trade on growth. 
less developed countries preferential access to markets in developed countries will facilitate growth among developing countries. ${ }^{23,24}$ The theory underlying the growth effects of this type of arrangement or other preferential arrangements is scant but growing, perhaps explaining the dearth of empirical work. Of the small amount of empirical work that has been carried out, the European Union has received the most attention.

Henrekson, Torstensson, and Torstensson (1997) study the growth effect of European integration. They find that membership in the European Union or the European Free Trade Area does significantly promote growth, and suggest that technology transfer is the main mechanism through which EU and EFTA membership affect growth. ${ }^{25}$ Landau (1995), on the other hand, finds that membership in the EU does not contribute to growth of member countries. He limits his sample to 17 wealthy OECD countries over 1950 to 1990; even when limiting the analysis to the 22 OECD countries, Henrekson, et al. still find a statistically significant positive effect of membership in the EU or EFTA. ${ }^{26}$. In related work, Ben-David (1993 and 1996) studies the extent to which European integration has promoted the convergence of incomes among EU countries. His general finding is that indeed, integration among European countries has brought about a general equalization of incomes. One might presume that this implies faster growth for some countries and not slower growth for others, in which case, this bloc has encouraged growth. ${ }^{27}$

Little has been done on regional integration in general. De Melo, Montenegro, and Panagariya (1992) estimate a growth equation including dummy variables for each trade bloc; the only significant dummy is for the Southern African Customs Union in the 1960-72

23 The trade and static welfare effects of the GSP have been studied by Baldwin and Murray, 1977, Truett and Truett, 1993, MacPhee and Oguledo, 1991, Tsanacas, 1989, MacPhee and Rosenbaum, 1989, Brown, 1987, and others.

24 Similar arguments were made by France when insisting that former colonies receive preferential access to the EEC under the Yaoundé and Lomé conferences.

25 Henrekson, et al. control for a large number of factors so that technological transfer is the only mechanism left by which European integration can affect growth.

26 The difference in results is perhaps explained by the fact that Henrekson, et al., control for membership in the EU or EFTA, while Landau only considers membership in the EU. Thus, Landau's control group will include members of EFTA, which may explain why the coefficient on EU membership is insignificant.

27 Other studies of European integration also find support for the hypothesis that integration led to growth; see, for example, Baldwin and Seghezza, 1996, Coe and Moghadam, 1993, Italianer, 1994, and Kokko, 1994. 
sub-period. Henrekson, et al., discuss why it is surprising that the influence of trade blocs is insignificant as well as discussing possible explanations for the insignificant result. When we adopt the De Melo, et al., approach, we too find generally insignificant results. However, alternative measures of regional integration, as discussed below, suggest that regional integration does increase growth rates. Assane and Pourgerami (1994) study the influence of the CFA monetary union on growth and find no direct result, though membership does allow the countries to better control price fluctuations, possibly indirectly leading to higher growth rates since it has been shown that lower inflation leads to increased growth.

\section{Empirical Framework}

From the discussion above, we find that there are a number of disjointed pieces of evidence that more international interactions lead to more trade. ${ }^{28}$ It seems clear that different types of international interactions are related. For example, foreign direct investment is thought to provide an alternative form of supplying a foreign country if tariffs are high, and empirical evidence suggests that trade and FDI are complementary. In appendix tables, we report statistically significant correlation coefficients for correlations between the international variables we include in our study (table A1) and between the international variables and the other included regressors (table A2). Indeed, most of the correlations are significant. Following in the same vein as Frankel and Romer (1996) and Levine and Renelt (1992), we note that omission of some international variables may therefore bias the results on other international variables. We therefore now turn to a more comprehensive investigation into the effects of foreign direct investment, trade in general, and preferential trade arrangements. By controlling for all forms of international interactions we can avoid the omitted variable bias that results from a fragmented approach.

In our analysis, we adopt a panel data approach. ${ }^{29}$ We borrow and extend Islam's

28 This is less true for the influence of membership in trade blocs on growth, where the evidence is rather mixed. The empirical work in this area is much less advanced.

29 Islam, 1995, offers important caveats against a cross-sectional approach. One drawback is that it does not allow for any differences in the production function across countries. Thus, we too adopt a panel data approach to allow for differences in production functions captured via the country-specific effect. 
approach, arriving at the following estimating equation:

$$
d y_{i t}=\alpha+\beta y_{i t-5}+\gamma C_{i t}+\tau T_{i t}+\nu_{i}+\epsilon_{i t},
$$

where $d y_{i t}$ is the growth rate of GDP per capita from period $t-5$ to period $t ; y_{i t-5}$ is country $i$ 's per capita income in period $t-5 ; C_{i t}$ is a set of control variables; $T_{i t}$ is a set of international interaction variables; $\nu_{i}$ is a country-specific error term; and $\epsilon_{i t}$ is the residual. ${ }^{30}$ We assume that continuous variables affect growth non-linearly, so they are entered as logs.

As controls, $C_{i t}$, we use the $\log$ of investment and government spending shares of GDP, the log of the population growth rate, and a measure of the initial stock of human capital, all of which are common control variables in empirical growth studies. ${ }^{31}$ We expect that the coefficient on investment will be positive. The standard neo-classical explanation is that increased investment raises the steady-state level of output per effective worker and therefore raises the growth rate for a given starting value of GDP. The endogenous growth explanation would rely on economies of scale and/or spillovers to explain the manner in which increased investment leads to increased growth. The expectation of the sign of the coefficient on government share is ambiguous, as it depends on what government is purchasing. ${ }^{32}$ For example, Barro (1997) considers government expenditures to proxy for outlays that do not improve productivity. The larger the share of GDP spent on non-productive government spending, the lower is expenditure on more productive endeavors and hence the lower is the growth rate. On the other hand, if the government is investing in education and infrastructure, or some other form of productive capital, the coefficient should be positive. We expect a negative coefficient on the population growth rate. ${ }^{33}$ In a neo-classical model, if the population is growing, more of the economy's investment is used to provide capital for new workers rather than to raise capital per worker. Thus, a higher rate of population growth

30 As explained below, we use 5-year periods as observations; thus, $d y_{i t}$ is country $i$ 's growth rate over the 5-year period prior to year $t$, and $y_{i t-5}$ is the per capita income at the beginning of each 5-year period.

31 The investment and government spending shares are averages over the five year period; population growth rate is measured over the five-year period; and human capital is measured at the beginning of each five-year period.

32 See Verspagen, 1992, who surveys growth theory with a focus on the role of government.

33 Ehrlich and Lui, 1997, discuss the impact of population growth on economic growth. 
has a negative effect on the steady-state level of output per effective worker. In addition, a higher fertility rate means that increased resources must be devoted to child-rearing rather than to production of goods, also reducing the growth rate. The measure of human capital is the average number of years of secondary schooling of males aged twenty-five and over the total population. ${ }^{34}$ Based on the assumption that more human capital helps a country absorb advanced knowledge from other countries, we expect that a higher initial stock of human capital will cause a country to grow more quickly towards its long-run GDP per capita.

A variety of measures of international interactions are included in the vector $T_{i t}$. They can be broadly classified as measuring foreign direct investment (FDI), general openness/trade, the existence of trade preferences, and membership in and characteristics of trade blocs. FDI differs qualitatively from domestic investment in that it is often thought of as an important channel through which advanced technology can be transferred from the source country to the host country. Thus, we would expect a positive relationship between foreign direct investment and growth. We measure FDI as the flow of all inward FDI as a share of. the recipient country's GDP.

To measure the extent to which a country is open, we use the "home bias" variable suggested by Wei (1996). Since a country's home bias is defined as its imports from itself in excess of what it would have imported from an otherwise identical foreign country, it captures all barriers to trade and thus is an inverse indicator of openness. ${ }^{35}$ The hypothesis that openness leads a country to grow faster implies that the coefficient on the home bias variable in our estimating equation should be negative. We expect this general index of the degree to which a country is closed to be advantageous given the data and measurement difficulties in directly measuring barriers to trade, especially with regard to non-tariff barriers.

We measure the volume of international trade in two ways. First, we include the

\footnotetext{
34 We also considered the average number of years of secondary schooling of females and males and the proportion of the population (males alone or females and males) that achieved secondary schooling. The results were largely unchanged.

35 We estimate the level of imports from an identical foreign country by estimating a gravity equation to explain bilateral trade flows, as documented in Wei, 1996.
} 
$\log$ of the trade share of GDP. ${ }^{36}$ Using total trade share makes two implicit assumptions. First, it assumes that imports and exports affect growth identically. Second, it assumes that the source and destination countries is irrelevant. Both assumptions seem unlikely. For example, endogenous growth theories that incorporate trade often model trade as facilitating growth via technology transfer. Then we might expect imports to have a larger impact on growth than exports, as imports will embody technology in the product as well as the transaction. In addition, Devereux and Lee (1998) and Baldwin (1992a) discuss the impact of increased domestic competition due to imports on growth rates. Obviously this result is absent for exports. Similarly, to stimulate growth the traded good must embody some appropriate technology. Thus, we divide trade flows according to direction and according their sources/destinations. We divide source and destination countries into three categories, richer, same, and poorer countries, where the categories are defined as countries with higher-, similar-, or lower-per capita GDP. ${ }^{37}$ This division of trade according to the relative income of the trade partner assumes that income is positively correlated with technology embodied in goods and transactions. If trade primarily affects growth by transmitting technology, interactions with higher-income countries may have a more beneficial impact than interactions with similar- or lower-income countries. On the other hand, technology from countries that are richer or poorer may not be appropriate to the country, so that technology adoption from countries that are more different may be below that adopted from more similar countries. Thus, we expect all trade flows to positively influence growth or to have no impact, but form

36 This variable is often suggested as a measure of openness; see, for example, Quah and Rauch, 1990. Yet the trade share will differ between small and large countries even if neither imposes any barriers to trade. Thus, this variable is not an appropriate measure of openness.

37 A country with a similar level of per capita income is defined as those twenty countries with per capita incomes closest to the country in question. This form of measurement may introduce some bias. Consider trade with rich countries by poor countries and vice versa. For those countries that are at the bottom or top of the per capita income ranking, trade with poorer or richer countries, respectively, will be zero, since there are no poorer or richer countries, and trade with richer or poorer countries, respectively, will be high since there are a large number of richer and poorer countries, respectively. If countries will low per capita incomes grow more slowly than countries with high per capita incomes (as shown by a correlation of 0.20 , significant at the $5 \%$ level), then the bias described above suggests that we should find a negative coefficient on imports and exports from rich countries and a positive coefficient on imports and exports from poor countries. While we do find the predicted signs for imports from richer and from poorer countries, we find the opposite sign for exports to richer and to poorer countries. This suggests that we are picking up more than the relationship induced by our measurement approach. 
no expectations regarding the relationship between magnitudes.

We empirically analyze the effect of trade preferences on growth in several different ways. First, non-reciprocal trade blocs. The former colonies of European Union member countries have been granted preferential, non-reciprocal access to the European Union since the 1970s under the Lomé and Yaoundé conventions. These countries are identified with a dummy variable labeled "Lomé." Preferential, non-reciprocal access was granted in order to benefit these countries, so we expect a positive coefficient on this variable. We also control for membership in reciprocal trade blocs. First, we identify countries which are members of any type of formal trade bloc with a dummy variable. ${ }^{38}$ In addition, we control for the type of trade blocs: trade preferences associations, free trade areas, and customs unions. ${ }^{39,40}$ The results of Rivera-Batiz and Romer suggest that we should find a positive coefficient on these variables.

We also control for some characteristics of trade blocs. First we consider a measure of the size of the trade bloc. For example, we might well expect that membership in a small trade bloc would have a smaller impact on growth than membership in a larger trade bloc, given that one theoretically suggested source of growth upon integration is economies of scale; such an effect would be larger for larger trade blocs. We measure the size of the trade bloc excluding the country's size by the total GDP of the bloc less the GDP of the country itself. The idea is to measure the extent to which joining the bloc increases the effective market for an individual country, as a larger market can facilitate the exploitation of economies to scale and increasing the return to $R \& D$, in turn leading to faster growth. Finally, we attempt to control for the likelihood of trade creation versus trade diversion. To do so, we include the standard deviation of per capita incomes within a trade bloc. Intuitively, a more diverse trade bloc increases the likelihood that the trade bloc will result in trade creation rather

38 We also attempted to use separate dummy variables indicating membership in each individual trade bloc. In general the estimated coefficients were insignificant.

39 As defined by Fieleke, 1992, a trade preferences association is a rather casual trade bloc which establishes lower barriers against imports from members than from non-members. A free trade area eliminates barriers imposed against other members, while a customs union also establishes a common tariff imposed against imports from non-members.

40 No country for which we have data is a member of a formal common market. 
than trade diversion, which should lead to increased technology diffusion. Thus, we expect to find a positive coefficient on this variable.

In order to take advantage of the cross-sectional and time-series variation in the data, we would ideally use a GLS, random effects estimation technique which optimally utilizes the cross-sectional and time-series variation in the data. However, this approach requires that the country-specific error, $\nu_{i}$, be independent of the regressors; otherwise the coefficient estimates are biased and inconsistent. Hausman specification tests soundly reject this assumption. ${ }^{41}$ We employ the fixed effects (within) estimator, which does not require this independence assumption. ${ }^{42}$

\section{The Data}

Most of the data are from the Penn World Table (5.6) data set, the most commonly used data set for empirical work on growth. ${ }^{43}$ Human capital stock data are from Barro and Lee (1996). Data on foreign direct investment are obtained from the IMF's International Financial Statistics. Data on trade flows is from the World Bank's Direction of Trade Statistics for 1970-1990. Additional data used in calculating the index of home bias were compiled from the World Almanac. The Penn World Table data are based on annual observations from 1950-1992, while the data in Barro-Lee data set are presented quinquennially from 1960-1990. Thus, we must use five-year time intervals since the human capital data is only available every five years. ${ }^{44}$ Finally, the data cover 1970 to 1989 ; the sample is chosen as the longest time period for which all variables are available for the widest selection of countries. Table 1 presents descriptive statistics for the variables included in the regression analysis. Because we are interested in comparing growth equations with different international integration variables, we limit the analysis to the same set of observations on the 74 countries for which data is available from all sources. This leaves us with a sample of 224

\footnotetext{
41 We report the results of the Hausman test in table 3.

42 Harrison, 1996, also adopts a fixed effects approach.

43 See Summers and Heston, 1991, for a description.

44 Islam, 1995, discusses other reasons why yearly time spans are too short for investigating growth.
} 
Table 1: Descriptive Statistics

\begin{tabular}{|c|c|c|c|c|}
\hline & Mean & Std. Dev. & Minimum & Maximum \\
\hline Per Capita GDP Growth ${ }^{1}$ & 7.55 & 14.00 & -38.25 & 61.42 \\
\hline Initial per Capita Income & $\$ 5,731$ & $\$ 4,611$ & $\$ 506$ & $\$ 18,095$ \\
\hline Investment Share & 19.01 & 8.03 & 1.20 & 42.04 \\
\hline Government Share & 17.47 & 6.94 & 7.62 & 40.24 \\
\hline Population Growth & 7.10 & 4.65 & -3.61 & 17.18 \\
\hline Initial Male Sec. Schooling ${ }^{2}$ & 1.46 & 1.04 & 0.03 & 5.07 \\
\hline Incoming FDI Share & 6.14 & 9.72 & 0.01 & 96.02 \\
\hline Home Bias & 5.38 & 1.99 & 0.64 & 9.78 \\
\hline Trade Share & 65.59 & 45.04 & 12.15 & 378.22 \\
\hline M Share from Richer Ctries & 23.97 & 20.82 & 0.00 & 102.28 \\
\hline M Share from Similar Ctries & 8.06 & 11.43 & 0.01 & 66.86 \\
\hline M Share from Poorer Ctries & 3.88 & 7.63 & 0.00 & 65.66 \\
\hline X Share from Richer Ctries & 17.18 & 14.69 & 0.00 & 76.46 \\
\hline X Share from Similar Ctries & 6.81 & 10.14 & 0.00 & 56.62 \\
\hline $\mathrm{X}$ Share from Poorer Ctries & 5.69 & 8.24 & 0.00 & 70.16 \\
\hline Member of Trade Bloc & 0.99 & 0.68 & 0 & 3 \\
\hline Lomé Country & 0.21 & 0.41 & 0 & 1 \\
\hline Member of TPA ${ }^{3}$ & 0.24 & 0.49 & 0 & 2 \\
\hline Member of FTA & 0.47 & 0.60 & 0 & 2 \\
\hline Member of CU & 0.22 & 0.41 & 0 & 1 \\
\hline Ag. Size of Rest Bloc Income $e^{4}$ & $\$ 1,221$ & $\$ 2,128$ & $\$ 0$ & $\$ 8,763$ \\
\hline Std. Dev. of Members' Incomes & 1969.35 & 1957.78 & 0.00 & 9413.50 \\
\hline Observations & 224 & & & \\
\hline \multicolumn{5}{|c|}{$\begin{array}{l}1 \text { Over five year periods. } \\
2 \text { The average number of years of secondary education attained by males over } 25 \text { years of age. } \\
{ }^{3} \text { Trade preferences association. } \\
{ }^{4} \text { In millions of constant dollars. }\end{array}$} \\
\hline
\end{tabular}

observations, spanning the countries listed in table 2.

Information on trade blocs is derived from a variety of sources. A table of preferential trade areas is included in the appendix. The table reveals a pattern of trade agreements formed between countries that are similar in location and development, with the exception of the Yaoundé and Lomé conventions and the Caribbean Basin Economic Recovery Act. 
Table 2: Sample of Countries

\begin{tabular}{|c|c|c|c|}
\hline \multicolumn{2}{|c|}{ The Americas } & \multicolumn{2}{|r|}{ Europe } \\
\hline $\begin{array}{c}\text { Argentina } \\
\text { Barbados } \\
\text { Bolivia } \\
\text { Brazil } \\
\text { Canada } \\
\text { Chile } \\
\text { Colombia } \\
\text { Costa Rica } \\
\text { Dominican Republic } \\
\text { Ecuador } \\
\text { El Salvador } \\
\text { Guatemala }\end{array}$ & $\begin{array}{c}\text { Guyana } \\
\text { Haiti } \\
\text { Honduras } \\
\text { Mexico } \\
\text { Panama } \\
\text { Paraguay } \\
\text { Peru } \\
\text { Trinidad and Tobago } \\
\text { United States } \\
\text { Uruguay } \\
\text { Venezuela }\end{array}$ & $\begin{array}{l}\text { Austria } \\
\text { Cyprus } \\
\text { Denmark } \\
\text { Finland } \\
\text { France } \\
\text { Germany } \\
\text { Greece } \\
\text { Iceland } \\
\text { Ireland } \\
\text { Italy }\end{array}$ & $\begin{array}{c}\text { Netherlands } \\
\text { Norway } \\
\text { Poland } \\
\text { Portugal } \\
\text { Spain } \\
\text { Sweden } \\
\text { Switzerland } \\
\text { Turkey } \\
\text { United Kingdom }\end{array}$ \\
\hline \multicolumn{2}{|c|}{ Africa } & \multicolumn{2}{|c|}{ Asia-Oceania } \\
\hline $\begin{array}{c}\text { Algeria } \\
\text { Benin } \\
\text { Cameroon } \\
\text { Egypt } \\
\text { The Gambia } \\
\text { Ghana } \\
\text { Kenya } \\
\text { Malawi }\end{array}$ & $\begin{array}{c}\text { Mali } \\
\text { Mauritius } \\
\text { Senegal } \\
\text { Sierra Leone } \\
\text { Togo } \\
\text { Tunisia } \\
\text { Zambia }\end{array}$ & $\begin{array}{l}\text { Australia } \\
\text { China } \\
\text { Fiji } \\
\text { Indonesia } \\
\text { Israel } \\
\text { Japan } \\
\text { Jordan } \\
\text { Korea }\end{array}$ & $\begin{array}{c}\text { Malaysia } \\
\text { New Zealand } \\
\text { Pakistan } \\
\text { Papua New Guine } \\
\text { Philippines } \\
\text { Singapore } \\
\text { Sri Lanka } \\
\text { Thailand }\end{array}$ \\
\hline
\end{tabular}

These latter trade arrangements occurred between developed and developing countries, and were negotiated primarily to aid the developing countries, granting them preferential, nonreciprocal, access to the EU and the United States, respectively. While the table lists all trade blocs that have been attempted, there is wide consensus that several have been quite unsuccessful. In particular, the Central American Common Market in its later days, the Latin American Free Trade Area, the Economic Community of Western African States, ASEAN, the Customs and Economic Union of Central Africa, the Andean Pact, the Preferential Trade Area for Eastern and Southern African States, the Southern African Development Coordination Conference, and the Communauté Economique de l'Afrique de l'Oest, are commonly mentioned as failed attempts at integration. Therefore we also try eliminating these trade blocs from the analysis, but the results are largely unchanged. We therefore report only the results including all trade blocs, given that the term "failure" is applied in 
an arbitrary manner.

\section{Results}

Our results are presented in Table 3 . The fit is reasonably good, and the fixed effects are always jointly significant. ${ }^{45}$ The baseline regression, which does not include any controls for international integration is given in column (1). Column (2) includes a control for inward FDI; columns (3)-(5) incorporate aspects of trade and openness. Columns (6)-(10) present regressions controlling for aspects of trade blocs, and column (11) gives the results obtained when all three aspects of international integration are included. We present the results in piecemeal fashion as well as comprehensively to illustrate the biases that may result when other aspects of international interactions are omitted from the growth regression.

We find evidence of convergence across the 74 countries in the sample, given that the coefficient on lagged income is significantly negative in all models. This suggests that countries with low initial income levels grow more quickly than countries with higher initial income levels. We also consistently find that the investment share contributes positively to growth, while the share of government expenditures contribute negatively to growth. The average number of years of secondary and higher schooling generally positively effects growth, but is rarely significant. ${ }^{46}$ Finally, population growth is negative in all specifications, but is also rarely significant. ${ }^{47}$

Inclusion of the first measure of international integration, the log of inward foreign direct investment, significantly increases the growth rate, as expected. ${ }^{48}$ Inclusion of FDI

45 In the interests of brevity, we. omit the fixed effect results. We also report the results from a Hausman specification-test which indicate that, for all models and at extreme significance, the variables are correlated with the country-specific error term, so that random effects are inappropriate.

46 de Mello, 1997, notes, that using standard measures of human capital accumulation may not be good at explaining the externalities and spillover effects of human capital stocks. This may explain the statistical insignificance of our result.

47 This lack of significance may be largely driven by outliers. When Guyana, Austria, Belgium-Luxembourg, Denmark, Finland, Germany, and the UK are omitted (all of which have abnormally low population growth), population growth remains negative and becomes significant.

48 We also tried adding an interaction term between human capital and foreign direct investment. The idea is that foreign direct investment will have a more positive effect on growth the more educated the work force of the host country, as the more educated the work force, the more technology that will be absorbed by the host country. While the results support the hypothesis, the variable is very unevenly distributed, with the United States and Canada having values several times the mean. 
Table 3

Fixed Effects Results

(standerd arron in porestheres)

\begin{tabular}{|c|c|c|c|c|c|c|c|c|c|c|c|}
\hline & (1) & (2) & (3) & (4) & (5) & (6) & (7) & (8) & (9) & (10) & (11) \\
\hline$\underset{\text { (base) }}{\log G D P}$ & $\begin{array}{l}-0.496^{* * *} \\
(0.038)\end{array}$ & $\begin{array}{l}-0.518^{* * *} \\
(0.058)\end{array}$ & $\begin{array}{l}-0.408^{* * * *} \\
(0.068)\end{array}$ & $\begin{array}{l}-0.502^{* 1 *} \\
(0.037)\end{array}$ & $\begin{array}{l}-0.523^{* 1.8} \\
(0.061)\end{array}$ & $\begin{array}{l}-0.531^{* * *} \\
(0.059)\end{array}$ & $\begin{array}{l}-0.522^{* \cdots *} \\
(0.058)\end{array}$ & $\begin{array}{l}-0.523^{* 0 .} \\
(8.057)\end{array}$ & $\begin{array}{l}-0.542^{* .0} \\
(0.05 s)\end{array}$ & $\begin{array}{l}-0.542^{* \cdots 0} \\
(0.055)\end{array}$ & $\begin{array}{l}-0.578 * \cdots \\
(0.088)\end{array}$ \\
\hline Log Gov't Exp. & $\begin{array}{l}-0.224^{* * \bullet} \\
(0.074)\end{array}$ & $\begin{array}{l}-0.176^{\circ} \\
(0.072)\end{array}$ & $\begin{array}{l}-0.220^{* * *} \\
(0.073)\end{array}$ & $\begin{array}{l}-0.211^{\cdots} \\
(0.073)\end{array}$ & $\begin{array}{r}-0.130 \\
(0.080)\end{array}$ & $\begin{array}{l}-0.240^{* 1 *} \\
(0.073)\end{array}$ & $\begin{array}{l}-0.248^{* * *} \\
(0.071)\end{array}$ & $\begin{array}{l}-0.218^{* * *} \\
(0.072)\end{array}$ & $\begin{array}{l}-0.218^{* 1 *} \\
(0.069)\end{array}$ & $\begin{array}{l}-0.218^{* * .} \\
(0.069)\end{array}$ & $\begin{array}{l}-0.126^{\circ} \\
(0.074)\end{array}$ \\
\hline$\underset{\text { (base) }}{\text { Male Secondary Ed. }}$ & $\begin{array}{r}0.032 \\
(0.028)\end{array}$ & $\begin{array}{r}0.007 \\
(0.028)\end{array}$ & $\begin{array}{r}0.022 \\
(0.028)\end{array}$ & $\begin{array}{r}0.017 \\
(0.029)\end{array}$ & $\begin{array}{r}0.029 \\
(0.028)\end{array}$ & $\begin{array}{r}0.041 \\
(0.029)\end{array}$ & $\begin{array}{l}0.047^{*} \\
(0.029)\end{array}$ & $\begin{array}{r}0.017 \\
(0.028)\end{array}$ & $\begin{array}{r}0.009 \\
(0.027)\end{array}$ & $\begin{array}{c}0.009 \\
(0.027)\end{array}$ & $\begin{array}{l}-0.003 \\
(0.026)\end{array}$ \\
\hline Log Pop. Growth & $\begin{array}{c}-0.027 \\
(0.018)\end{array}$ & $\begin{array}{r}-0.024 \\
(0.017)\end{array}$ & $\begin{array}{l}-0.017 \\
(0.018)\end{array}$ & $\begin{array}{l}-0.023 \\
(0.018)\end{array}$ & $\begin{array}{l}-0.019 \\
(0.018)\end{array}$ & $\begin{array}{r}-0.019 \\
(0.018)\end{array}$ & $\begin{array}{r}-0.015 \\
(0.018)\end{array}$ & $\begin{array}{l}-0.014 \\
(0.018)\end{array}$ & $\begin{array}{r}-0.011 \\
(0.017)\end{array}$ & $\begin{array}{l}-0.011 \\
(0.017)\end{array}$ & $\begin{array}{r}-0.009 \\
(0.017)\end{array}$ \\
\hline Log Dom. Inv. & $\begin{array}{c}0.093^{* *} \\
(0.042)\end{array}$ & $\begin{array}{c}0.073^{\circ} \\
(0.040) \\
\end{array}$ & $\begin{array}{c}0.094^{* *} \\
(0.041)\end{array}$ & $\begin{array}{r}0.061 \\
(0.044)\end{array}$ & $\begin{array}{l}0.130^{* * .} \\
(0.043)\end{array}$ & $\begin{array}{l}0.119^{* * *} \\
(0.042)\end{array}$ & $\begin{array}{c}0.083^{* *} \\
(0.042)\end{array}$ & $\begin{array}{l}0.106^{* \cdots *} \\
(0.041)\end{array}$ & $\begin{array}{l}0.106^{* 0 *} \\
(0.039) \\
\end{array}$ & $\begin{array}{l}0.107^{\circ 01} \\
(0.039) \\
\end{array}$ & $\begin{array}{l}0.122 \\
(0.040)\end{array}$ \\
\hline Log Inward FDI & - & $\begin{array}{l}0.041 \\
(0.011)\end{array}$ & - & - & - & - & - & - & - & - & $\begin{array}{l}0.030^{* 01} \\
(0.011)\end{array}$ \\
\hline Home Bias & - & - & $\begin{array}{l}0.082^{* *} \\
(0.035)\end{array}$ & - & - & - & - & - & - & - & - \\
\hline Log Openness & - & - & - & $\begin{array}{l}0.112^{20} \\
(0.051)\end{array}$ & - & - & - & - & - & - & - \\
\hline Log Exp to Rich & - & - & - & - & $\begin{array}{l}0.161^{* * *} \\
(0.049)\end{array}$ & - & - & - & - & - & $\begin{array}{l}0.114^{* *} \\
(0.047)\end{array}$ \\
\hline Log Exp to Same & - & - & - & - & $\begin{array}{l}-0.015 \\
(0.032)\end{array}$ & - & - & - & - & - & $\begin{array}{l}0.003 \\
(0.031)\end{array}$ \\
\hline Log Exp to Poor & - & - & - & - & $\begin{array}{l}-0.027 \\
(0.032)\end{array}$ & - & - & - & - & - & $\begin{array}{l}-0.011 \\
(0.030)\end{array}$ \\
\hline Log Imp from Rich & - & - & - & - & $\begin{array}{l}-0.143^{* * *} \\
(0.048)\end{array}$ & - & - & - & - & - & $\begin{array}{l}-0.122^{* * *} \\
(0.045)\end{array}$ \\
\hline Log Imp from Same & - & - & - & - & $\begin{array}{c}0.043 \\
(0.036)\end{array}$ & - & - & - & - & - & $\begin{array}{c}0.017 \\
(0.034)\end{array}$ \\
\hline Log Imp from Poor & - & - & - & - & $\begin{array}{r}0.022 \\
(0.035)\end{array}$ & - & - & - & - & - & $\begin{array}{c}0.014 \\
(0.033)\end{array}$ \\
\hline $\begin{array}{l}\text { St.dev. of } \\
\text { Mmbr Incomes }\end{array}$ & - & - & - & - & - & - & - & - & $\begin{array}{l}0.301 * * * \\
(0.063)\end{array}$ & $\begin{array}{l}0.297^{* * *} \\
(0.090)\end{array}$ & $\begin{array}{l}0.236 * * * \\
(0.065)\end{array}$ \\
\hline Bloc Size & - & - & - & - & - & - & - & $\begin{array}{l}0.240^{\circ 0 *} \\
(0.076)\end{array}$ & - & $\begin{array}{c}0.002 \\
(0.102)\end{array}$ & - \\
\hline Trade Bloc Mmbr & - & - & - & - & - & $\begin{array}{l}0.059^{* \bullet} \\
(0.028)\end{array}$ & - & - & - & - & - \\
\hline PTA & - & - & - & - & - & - & $\begin{array}{c}0.007 \\
(0.040)\end{array}$ & - & - & - & - \\
\hline FTA & - & - & - & - & - & - & $\begin{array}{l}0.103^{\circ \cdots *} \\
(0.038)\end{array}$ & - & - & - & - \\
\hline Customs Union & - & $\sim$ & - & - & - & - & $\begin{array}{c}0.095^{\circ} \\
(0.052)\end{array}$ & - & - & - & - \\
\hline Lomé Ctry & - & - & - & - & - & $\begin{array}{r}0.152 \\
(0.117) \\
\end{array}$ & $\begin{array}{r}0.125 \\
(0.120) \\
\end{array}$ & - & - & - & - \\
\hline $\mathrm{R}^{2}$ Within & 0.42 & 0.47 & 0.44 & 0.43 & 0.47 & 0.45 & 0.48 & 0.45 & 0.49 & 0.49 & 0.56 \\
\hline F-test ${ }^{* * *}$ & 3.54 & 3.95 & 3.73 & 3.46 & 3.12 & 3.76 & 4.11 & 3.90 & 4.35 & 4.32 & 3.97 \\
\hline Hausman-test ${ }^{* * \bullet}$ & 81.75 & 100.44 & 90.38 & 87.92 & 78.79 & 95.36 & 141.43 & 97.46 & 118.03 & 118.63 & 175.02 \\
\hline
\end{tabular}

"*", ", ", represent significance at the one, five and ten percent level, respectively.

(base) indicates that the value used in the regression is from the first year of each five year grouping. 
significantly reduces the estimated coefficient on domestic investment (by $22 \%$ ). We expect that the larger estimated coefficient on domestic investment when FDI is omitted is due to the correlation between the two variables. ${ }^{49}$ The two forms of investment will both be motivated, at least in part, by the same factors (e.g., a good return on investment). Thus, when FDI is omitted, the estimated coefficient on domestic investment will pick up not only its direct effect on growth, but also will reflect the influence of FDI on growth rates.

We next consider the effect of trade and openness on growth. The estimated effect of "Home Bias," the variable broadly measuring how closed a country is, is surprising. Rather than being negative, as expected, it is positive and significant. In contrast, the effect of trade share, often used as a measure of openness, reported in column (4), indicates that more openness (less closedness) leads to higher growth. ${ }^{50}$ However, from table A2 we see that the measure of how closed the economy is, home bias, is statistically significantly positively correlated (at 0.33 ) with the trade share. While at first a positive correlation may seem counterintuitive, consider the following. Trade share is determined not only by trade barriers, but also by natural characteristics of the country (e.g., factor endowments relative to world endowments, distance from other countries, etc.). Countries that naturally (i.e., in the absence of policy) would have large trade shares may be precisely the most likely countries to impose trade barriers. Then a higher home bias will not only indicate that a country is closed but will also indicate a country with a large trade share. Thus, the coefficient on home bias may be picking up primarily the positive influence of trade share on growth, given the positive correlation between home bias and trade share.

Finally, we consider the source of imports and exports; that is, we disaggregate the trade share variable into exports and imports to/from countries with higher incomes, similar incomes, and lower incomes. Only trade to and from richer countries is significant, which is largely consistent with theory. However, imports from richer countries are estimated to re-

49 Table A3 in the appendix shows that FDI and domestic investment are statistically significantly correlated, with a correlation coefficient of 0.54 .

50 In addition, studies which have considered alternative measures of openness, in particular Harrison, 1996, also show that more openness leads to higher growth. 
duce growth, while exports to rich countries are associated with higher growth. Endogenous growth theories that incorporate international trade suggest that imports should lead to diffusion of technology and hence growth. One explanation is that the goods that are imported from richer countries do not embody the technology that is appropriate for poorer countries. For example, comparative advantage and casual empiricism suggest that imports from richer countries will embody technology that relies heavily on capital (physical or human), while poorer countries are relatively well endowed with unskilled labor. If recipient countries adopt the inappropriate technology, their growth rates may fall. Alternatively, imports from richer countries may be processed in the recipient country and then re-exported. Then the effect of imports on growth is embodied not only in the coefficient on imports, but also in part by the coefficient on exports. That is, though the partial derivative is negative, the total derivative is positive. ${ }^{51}$. Unfortunately we do not have sufficient data on processing and re-exporting to verify this hypothesis.

Consider now the variables relating to trade blocs. Columns (6) and (7) consider how simple membership in a trade bloc may affect growth. We find evidence that belonging to a trade bloc significantly increases growth. ${ }^{52}$ Having preferential, non-reciprocal access to the EU through the Lomé convention is insignificant, though positive as one might expect. ${ }^{53}$ Column (7) separates membership by type of trade bloc. We find that membership in a free trade area or a customs union significantly increases growth, though membership in a trade preferences association, the least integrated, least formal type of trade bloc, has no significant impact on growth.

We then consider how characteristics of the trade bloc may affect growth. We consider two aspects of a trade bloc: (log of) the sum of GDP of the bloc members not including

51 Henry Wan suggested this explanation in private communication.

52 We also tried including a separate dummy variable for each trade blocs, but in general none were significant. In addition, note from the descriptive statistics in table 1 that a country may belong to more than one trade bloc, in which case our dummy variable indicating membership in a trade bloc will take a value higher than 1 . We also estimate the equation with a dummy variable equal to 1 if a country belongs to at least 1 trade bloc and 0 otherwise; the results are unchanged.

53 Many of the Lomé countries are omitted from the sample because information on other variables, especially foreign direct investment, is missing. This may explain the insignificance. 
the member country and the standard deviation of member incomes. The former is expected to measure the possibility of returns to scale in $R \& D$ (given a larger market) and the latter to measure the likelihood of trade creation rather than diversion. When each is included separately, we find a statistically significantly positive effect. However, when both are included, only the latter effect is significant.

Finally, consider the results in column (11), which include controls for FDI, for trade flows from richer, similar, and poorer countries, and the standard deviation of trade bloc members income. All of the international variables remain robust in terms of sign and significance, though the magnitude of the coefficients shrink somewhat. The latter effect is due to the fact that the variables are correlated, so that omitting them in the initial regressions caused the included variables to pick up the effect of the omitted variables. The overall fit is improved. Thus, we conclude that controlling for all forms of international integration is important. While omitting some forms will not lead to wrong inferences with regard to sign and significance, magnitudes will be overstated, as estimated coefficients pick up the effects of omitted variables as well as the direct effect of the regressor.

\section{Conclusions}

In this paper, we have provided examples of theoretical propositions regarding the influence of international interactions on growth, a summary of the empirical evidence of these interactions, and evidence of the importance not only of international transactions for growth, but the importance of measuring these interactions comprehensively. What we found in the empirical literature is a piecemeal approach to addressing the issue of international interactions and growth. There are a variety of mechanisms through which active engagement with the rest of the world can facilitate growth. Our evidence reveals that indicators of openness, integration, FDI, and preferential treatment are sufficiently correlated that an analysis of one in the absence of the others is not meaningful. To date, the literature lacks a single study incorporating these various influences and hence fails to provide an adequate 
picture of how international interactions contribute to growth, especially, with respect to magnitude.

We have also identified areas of the literature that remain under-explored. In particular, the influence of preferential trading arrangements of one sort or another on growth is currently an open question. Theory gives ambiguous predictions: depending on the model, regional integration may increase or decrease growth or have no influence at all. The empirical evidence, what little exists, is also ambiguous. The importance of this question is clear when one attempts to understand the motivation for arrangements such as Lomé, the Generalized System of Preferences, and the Caribbean Basin Initiative of the United States. These programs are rationalized as promoting growth in less developed regions by granting liberal access to developed markets. While there is evidence that trade preferences do facilitate trade between participating countries, the consequences for growth are neither well understood nor well explored.

Finally, our empirical work employs a single dataset and econometric technique in an effort to consistently examine the several potential contributors of international engagement to growth. We find broad support for the notion that trade, FDI, and regional integration generally contribute to growth in per capita incomes in the 1970s and 1980s. We present results for each mechanism separately and together in order to illustrate the robustness of the results to omitted variable bias. Our results can be broadly characterized as follows: trading more, but with the right countries, foreign direct investment, and trade preferences between countries with disparate incomes lead to enhanced growth of per capita incomes. In addition, a comprehensive regression reveals that these results continue to hold, but with somewhat reduced strength. The estimated magnitudes of the effect of the statistically significant variables fall by 15 to $30 \%$ when all forms of international interactions are included. This result highlights the importance of a comprehensive (versus piecemeal) analysis of international interactions and growth. 


\section{REFERENCES}

Assane, Djeto and Abbas Pourgerami, January 1994, "Monetary Co-operation and Economic Growth in Africa: Comparative Evidence from the CFA-Zone Countries," Journal of Development Studies, 30(2), 423-442.

Balasubramanyam, V.N., M. Salisu, and D. Sapsford, January 1996, "Foreign Direct Investment and Growth in EP and IS Countries," The Economic Journal, 106, 92-105.

Baldwin, Richard E., April 1992a, "On the Growth Effects of Import Competition," NBER Working Paper \#4045.

Baldwin, Richard E., February 1992b, "Measurable Dynamic Gains from Trade," Journal of Political Economy, 100(1), 162-174.

Baldwin, Richard E. and E. Seghezza, 1996, "Growth and European Integration: Towards an Empirical Assessment," mimeo, Graduate Institute of International Studies, Geneva.

Baldwin, Robert E. and Tracy Murray, March 1977, "MFN Tariff Reductions and Developing Country Trade Benefits under the GSP," The Economic Journal, 87(345), 30-46.

Barro, Robert, 1997, Determinants of Economic Growth, Cambridge, MA: The MIT Press.

Barro, Robert and Jong-Wha Lee, May 1996, "International Measures of Schooling Years and Schooling Quality," American Economic Review Papers and Proceedings, 86(2), 218-223.

Ben-David, Dani, August 1993, "Equalizing Exchange: Trade Liberalization and Income Convergence," Quarterly Journal of Economics, 108, 653-679.

Ben-David, Dani, May 1996, "Trade and Convergence Among Countries," Journal of International Economics, 40(3-4), 279-298.

Ben-David, Dani and Michael B. Loewy, July 1997, "Free Trade, Growth, and Convergence," NBER Working Paper \#6095.

Ben-David, Dani and Michael B. Loewy, May 1998, "Knowledge Dissemination, Capital Accumulation, Trade, and Endogenous Growth," mimeo.

Borensztein, Eduardo, José De Gregorio, and Jong-Wha Lee, 1995, "How Does Foreign Direct Investment Affect Economic Growth?," NBER Working Paper \#5057.

Brown, D.K., July 1987, "General Equilibrium Effects of the U.S. Generalized System of Preferences," Southern Economic Journal, 54(1), 27-47.

Coe, David T. and Elhanan Helpman, May 1995, "International R\&D Spillovers," European Economic Review, 39(5), 859-887. 
Coe, David T. and Reza Moghadam, 1993, "Capital and Trade as Engines of Growth in France: An Application of Johansen's Cointegration Methodology," IMF Working Paper.

Coe, David T., Elhanan Helpman, and Alexander W. Hoffmaister, January 1997, "NorthSouth R\&D Spillovers," The Economic Journal, 107(440), 134-149.

De la Torre, Augusto and Margaret R. Kelly, 1992, "Regional Trade Arrangements," International Monetary Fund Occasional Paper 93.

De Melo, J., C. Montenegro, and A. Panagariya, 1992, "Regional Integration Old and New: Issues and Evidence," mimeo, World Bank.

De Mello, Luiz R., Jr., October 1997, "Foreign Direct Investment in Developing Countries and Growth: A Selective Survey," Journal of Development Studies, 34(1), 1-34.

Devereux, Michael B. and Khang Min Lee, 1998, "Dynamic Gains from Trade, Revisited," mimeo.

Devereux, Michael B. and Beverly J. Lapham, February 1994, "The Stability of Economic Integration and Endogenous Growth," Quarterly Journal of Economics, 109, 299-305.

Dollar, D., 1991. "Outward-Oriented Developing Economies Really Do Grow More Rapidly: Evidence from 95 LDCs, 1976-85," Economic Development and Cultural Change, 523544.

Edwards, Sebastian, September 1993, "Openness, Trade Liberalization, and Growth in Debeloping Countries," Journal of Economic Literature, 31, 1358-1393.

Edwards, Sebastian, 1992, "Trade Orientation, Distortions, and Growth in Developing Countries," Journal of Development Economics, 39(1), 31-57.

Ehrlich, Isaac and Francis Lui, January 1997, "The Problem of Population and Growth: A Review of the Literature from Malthus to Contemporary Models of Endogenous Population and Endogenous Growth," Journal of Economic Dynamics and Control, 21(1), 205-242.

El-Agraa, Ali M., 1994, "Economic Integration," chapter 6 in Economic Development, Enzo Grilli and Dominick Salvatore, eds. Westport, CT: Greenwood Press.

Feder, Gershon, February/April 1983, "On Exports and Economic Growth," Journal of Development Economics, 12(1/2), 59-73.

Fieleke, Norman S., May/June 1992, "One Trading World, or Many: The Issue of Regional Trading Blocs," New England Economic Review, 3-20.

Fischer, Stanley, 1993, "The Role of Macroeconomic Factors in Growth," Journal of Monetary Economics, 32, 485-512. 
Frankel, Jeffrey A. and David Romer, March 1996, "Trade and Growth: An Empirical Estimation," NBER Working Paper \#5476.

Grossman, Gene and Elhanan Helpman, 1991a, Innovation and Growth in the Global Economy, Boston: MIT Press.

Grossman, Gene and Elhanan Helpman, 1991b, "Trade, Knowledge Spillovers, and Growth," European Economic Review, 35(3), 517-526.

Harrison, Ann, 1996, "Openness and Growth: A Time-Series, Cross-Country Analysis for Developing Countries," Journal of Development Economics, 48, 419-447.

Henrekson, Magnus, Johan Torstensson, and Rasha Torstensson, 1997, "Growth Effects of European Integration," European Economic Review, 41, 1537-1557.

Islam, Nazrul, November 1995, "Growth Empirics: A Panel Data Approach," Quarterly Journal of Economics, 110(4), 1127-1170.

Italianer, Alexander, 1994, "Whither the Gains from European Economic Integration," Revue Economique, 45(3), 689-702.

Keller, Wolfgang, June 1997, "Are International R\&D Spillovers Trade-Related? Analyzing Spillovers among Randomly Matched Trade Partners," NBER Working Paper \#6065.

Knight, Malcolm, Normal Loayza, and Delano Villanueva, 1993, "Testing the Neo-Classical Theory of Economic Growth," International Monetary Fund Staff Papers, 40(3), 512541.

Kokko, A., 1994, "Sweden, EU Membership, Investment, and Growth," World Economy, 17, $667-678$.

Kormendi, Roger C. and Philip G. Mequire, September 1985, "Macroeconomic Determinants of Growth: Cross-Country Evidence," Journal of Monetary Economics, 16(2), 141-163.

Landau, D., 1995, "The Contribution of the European Common Market to the Growth of its Member Countries: An Empirical Test," Weltwirtschaftliches Archiv, 131, 774-782.

Lawrence, Robert Z., 1996, Regionalism, Multilateralism, and Deeper Integration, Washington, DC: The Brookings Institution.

Leamer, Edward E., 1988, "Measure of Openness,"in Trade Policy and Empirical Analysis, Baldwin, R., ed., Chicago: University of Chicago Press.

Lee, Jong Wha, 1993, "International Trade, Distortions, and Long-Run Economic Growth," International Monetary Fund Staff Papers, 40(2), 299-328.

Lee, Feng Yao and William E. Cole, Summer 1994, "Simultaneity in the Study of Exports and Economic Growth," International Economic Journal, 8(2), 33-41. 
Levine, Ross and David Renelt, September 1992, "A Sensitivity Analysis of Cross-Country Growth Regressions," American Economic Review, 82(4), 942-963.

Long, Ngo Van and Kar-yiu Wong, 1997, "Endogenous Growth and International Trade: A Survey," in Dynamics, Economic Growth, and International Trade, Jensen, Bjarne S. and Kar-yiu Wong, eds., Ann Arbor: University of Michigan Press.

MacPhee, C.R. and V.I. Oguledo, December 1991, "The Trade Effects of the U.S. Generalized System of Preferences," Atlantic Economic Journal, 19(4), 19-26.

MacPhee, C.R. and D.I. Ronsenbaum, June 1989, "Has the European Community GSP Increased LDC Exports?" Atlantic Economic Journal, 21(6), 823-41.

Nadal de Simone, Francisco D.A., April 1995, "A Macroeconomic Perspective of AFTA's Problems and Prospects," Contemporary Economic Policy, 13(2), 49-62.

Papageorgiou, D., M. Michaely, and A. Choksi, eds., 1991, Liberalizing Foreign Trade: Lessons of Experience in the Developing World, Cambridge, MA: Basil Blackwell.

Peretto, Pietro F., March 1996, "Growth, Market Structure, and the Welfare Effects of Economic Integration," mimeo.

Pritchett, Lant, 1991, "Measuring Outward Orientation in Developing Countries: Can it be Done?", PRE working paper \#566.

Quah, Danny and James E. Rauch, October 1990, "Openness and the Rate of Economic Growth," University of California, San Diego, Working paper.

Rivera-Batiz, Luis A. and Paul M. Romer, May 1991, "Economic Integration and Endogenous Growth," Quarterly Journal of Economics, 106, 531-556.

Roubini, Nouriel and Xavier Sala-i-Martin, October 1991, "Financial Development, the Trade Regime, and Economic Growth," NBER Working Paper \#3876.

Sala-i-Martin, Xavier X., May 1997, "I Just Ran Two Million Regressions," American Economic Review Papers and Proceedings, 87(2), 178-183.

Saltz, Ira S., 1992, "The Negative Correlation between Foreign Direct Investment and Economic Growth in the Third World: Theory and Evidence," Rivista Internazionale di Scienze Economiche e Commerciali, 39(7), 617-633.

Sinha, Tapen and Dipendra Sinha, 1996, "An Empirical Investgation into the Relationship between Openness and Economic Growth: Evidence from Asia," Rivista Internazionale di Scienze Economiche e Commerciali, 43(2), 359-370.

Solow, Robert M., February 1956, "A Contribution to the Theory of Economic Growth," Quarterly Journal of Economics, 70(1), 65-94. 
Summers, Robert and Alan Heston, 1991, "Penn World Table (Mark 5): An Expanded Set of International Comparisons, 1950-1985," Quarterly Journal of Economics, 106(2), 327-368.

Swan, Trevor W., November 1956, "Economic Growth and Capital Accumulation," Economic Record, 32, 334-361.

Thomas, Vinod, Nadav Halevi, and Julie Stanton, 1991, "Does Policy Reform Improve Performace?," Background paper for the World Development Report.

Truett, D.B. and L.J. Truett, 1993, "Trade Preferences and Exports of Manufactures: A Case Study of Bolivia and Brazil," Weltwirtschaftslices Archiv, 129(3), 573-590.

Tsai, Pan-Long, June 1994, "Determinants of Foreign Direct Investment and Its Impact on Economic Growth," Journal of Economic Development, 19(1), 137-163.

Tsanacas, D.P., 1989, "Market Share Effects of the Lomé Convention and the GSP," in The Modern International Environment. Greenwich, Conn. and London: JAI Press, 129-207.

Van den Berg, Nedrik, 1996, "Does Simultaneity Exaggerate Empirical Tests of the TradeGrowth Relationship?", Applied Economics Letters, 3(4) 225-231.

Verspagen, Bart, Fall 1992, "Endogenous Innovation in Neo-Classical Growth Models: A Survey," Journal of Macroeconomics, 14(4), 631-662.

Walz, Uwe, 1998, "Does an Enlargement of a Common Market Stimulate Growth and Convergence?," Journal of International Economics, 45, 297-321.

Walz, Uwe, 1997a, "Dynamic Effects of Economic Integration: A Survey," Open Economies Review, 8(3), 309-326.

Walz, Uwe, February 1997b, "Innovation, Foreign Direct Investment, and Growth," Economica, 64, 63-79.

Wei, Shang-Jin, 1996, “Intra-National Versus International Trade: How Stubborn Are Nations in Global Integration?," NBER Working Paper \#5531.

Whalley, John, 1985, Trade Liberalization among Major World Trading Areas, Cambridge: MIT Press.

Whalley, John and Colleen Hamilton, 1997, The Trading System After the Uruguay Round, Washington, DC: Institute for International Economics.

Wolf, Holger C., 1993, "Trade Orientation Measurement and Consequences," Estudios de Economia, 20(0), 49-86. 


\section{Appendix}

Table A3: Preferential Trading Arrangements Through 1989

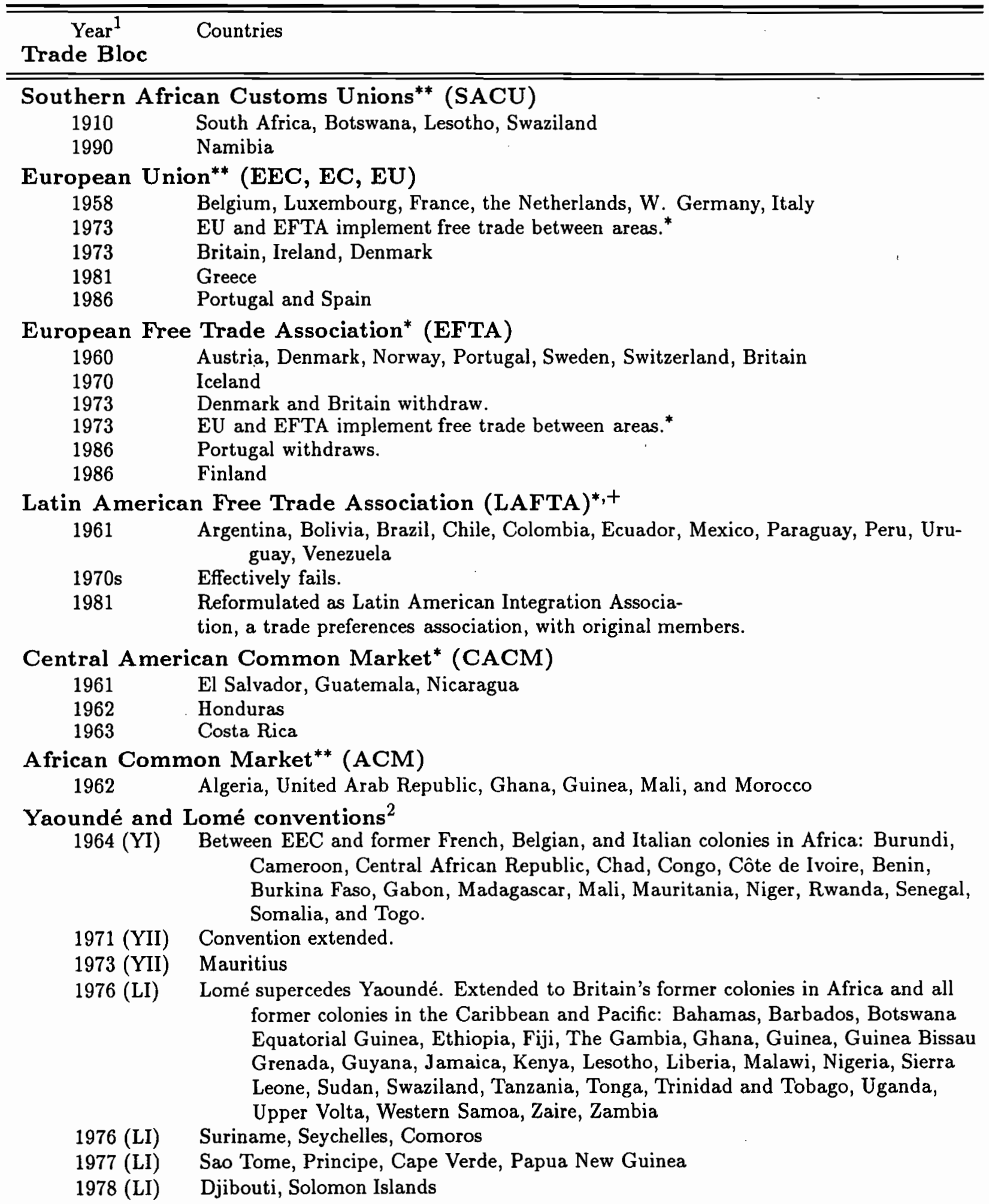


Table A1: Correlations Among International Variables

\begin{tabular}{|c|c|c|c|c|c|c|c|c|c|c|c|c|c|c|c|}
\hline & $\begin{array}{l}\mathrm{F} \\
\mathrm{D} \\
\mathrm{I}\end{array}$ & $\begin{array}{c}\mathrm{H} \\
\mathbf{o} \\
\mathbf{m} \\
\mathbf{e} \\
\mathbf{B} \\
\mathbf{i} \\
\mathbf{a} \\
\mathbf{s}\end{array}$ & $\begin{array}{l}\mathrm{T} \\
\mathrm{r} \\
\mathrm{a} \\
\mathrm{d} \\
\mathrm{e} \\
\mathrm{S} \\
\mathrm{h} \\
\mathrm{r}\end{array}$ & $\begin{array}{l}\mathrm{R} \\
\mathrm{i} \\
\mathrm{c} \\
\mathrm{h} \\
\mathrm{X}\end{array}$ & $\begin{array}{l}\mathrm{S} \\
\mathbf{a} \\
\mathbf{m} \\
\mathbf{e} \\
\mathrm{X}\end{array}$ & $\begin{array}{l}\mathrm{P} \\
0 \\
0 \\
\mathrm{r} \\
\mathrm{X}\end{array}$ & $\begin{array}{l}\mathbf{R} \\
\mathbf{i} \\
\mathbf{c} \\
\mathbf{h} \\
\mathrm{M}\end{array}$ & $\begin{array}{c}\mathrm{S} \\
\mathrm{a} \\
\mathrm{m} \\
\mathrm{e} \\
\mathrm{M}\end{array}$ & $\begin{array}{c}\mathrm{P} \\
\mathbf{o} \\
\mathbf{o} \\
\mathbf{r} \\
\mathrm{M}\end{array}$ & $\begin{array}{c}\mathrm{L} \\
\text { o } \\
\mathrm{m} \\
\text { é }\end{array}$ & $\begin{array}{l}\mathrm{A} \\
\mathbf{n} \\
\mathrm{y} \\
\mathrm{B} \\
\mathrm{I} \\
\mathbf{o} \\
\mathrm{c}\end{array}$ & $\begin{array}{l}\mathrm{P} \\
\mathrm{T} \\
\mathrm{A}\end{array}$ & $\begin{array}{l}\mathrm{F} \\
\mathrm{T} \\
\mathrm{A}\end{array}$ & $\underset{\mathrm{U}}{\mathrm{C}}$ & $\begin{array}{l}\text { B } \\
\text { l } \\
\text { o } \\
\text { c } \\
\text { S } \\
\text { t } \\
d\end{array}$ \\
\hline Home Bias & -.83 & & & & & & & & & & & & & & \\
\hline Trade Shr ${ }^{*}$ & -.19 & .33 & & & & & & & & & & & & & \\
\hline Rich $X^{*}$ & -.52 & .72 & .40 & & & & & & & & & & & & \\
\hline Samẹ $X^{*}$ & .47 & -.57 & .32 & -.55 & & & & & & & & & & & \\
\hline Poor $\mathrm{X}^{*}$ & .40 & -.46 & .41 & -.36 & .71 & & & & & & & & & & \\
\hline Rich $\mathbf{M}^{*}$ & -.55 & .76 & .44 & .93 & -.57 & -.32 & & & & & & & & & \\
\hline Same $M^{*}$ & .42 & -.51 & .40 & -.51 & .91 & .75 & -.47 & & & & & & & & \\
\hline Poor $\mathrm{M}^{*}$ & .45 & -.48 & .44 & -.37 & .69 & .88 & -.34 & .77 & & & & & & & \\
\hline Lomé & -.56 & .61 & .23 & .38 & -.29 & -.19 & .37 & -.27 & -.23 & & & & & & \\
\hline Any Bloc & & & & & & -.15 & & & -.15 & .18 & & & & & \\
\hline PTA & & & & .29 & -.24 & & .18 & -.30 & & & .35 & & & & \\
\hline FTA & -.19 & .17 & & & & & & & -.19 & & .59 & -.24 & & & \\
\hline $\mathrm{CU}$ & .14 & -.20 & & & .28 & & -.14 & .27 & .17 & .14 & .27 & -.26 & & & \\
\hline Bloc Std. & .36 & -.33 & & & .34 & .17 & -.19 & .31 & .23 & -.20 & .56 & .16 & .18 & .53 & \\
\hline Bloc Size & .41 & -.40 & & -.20 & .41 & .16 & -.23 & .37 & .25 & -.27 & .26 & & .66 & .78 & \\
\hline
\end{tabular}


Table A2: Correlations between International and Control Variables

\begin{tabular}{lrrrrr}
\hline \hline & $\begin{array}{c}\text { Initial } \\
\text { GDP }\end{array}$ & $\begin{array}{c}\text { Govt. } \\
\text { Share }\end{array}$ & $\begin{array}{c}\text { Initial } \\
\text { Sec. Ed. }\end{array}$ & $\begin{array}{r}\text { Pop. } \\
\text { Growth }\end{array}$ & $\begin{array}{r}\text { Invest. } \\
\text { Share }\end{array}$ \\
\hline \hline FDI Share* & 0.67 & -0.41 & 0.50 & -0.40 & 0.54 \\
Home Bias & -0.81 & 0.48 & -0.61 & 0.52 & -0.63 \\
Trade Share* & & 0.25 & & & \\
X Sh. to Richer & -0.63 & 0.27 & -0.56 & 0.44 & -0.32 \\
X Sh. to Same* & 0.74 & -0.19 & 0.57 & -0.62 & 0.48 \\
X Sh. to Poorer* & 0.69 & -0.29 & 0.56 & -0.48 & 0.46 \\
M Sh. to Richer* & -0.66 & 0.31 & -0.55 & 0.45 & -0.35 \\
M Sh. to Same* & 0.77 & -0.19 & 0.61 & -0.63 & 0.42 \\
M Sh. to Poorer* & 0.72 & -0.30 & 0.58 & -0.52 & 0.47 \\
Lomé & -0.52 & 0.44 & -0.38 & 0.24 & -0.54 \\
Member of Trade Bloc & & 0.13 & & & -0.30 \\
Member of PTA & -0.19 & & & 0.23 & \\
Member of FTA & -0.14 & 0.18 & & & -0.29 \\
Member of CU & 0.22 & & & -0.45 & \\
Bloc Std. Dev. Income & 0.35 & & 0.22 & -0.44 & 0.19 \\
Bloc Size & 0.38 & & 0.17 & -0.53 & 0.21 \\
\hline \hline A blank entry indicates that the correlation was not significant at the 5\% level. \\
* In logs. \\
\hline \hline
\end{tabular}


Yaoundé and Lomé conventions continued

1979 (LI) Tuvalu, Dominica, St. Lucia, Kiribati

1980 (LI) St. Vincent and the Grenadines

1981 (LII) Convention extended.

1981 (LII) Vanuatu

1982 (LII) Antigua and Barbuda, Belize, and Zimbabwe

1986 (LIII) Convention extended.

1986 (LIII) Mozambique

Australia/New Zealand Free Trade Area* (ANZERTA)

$1966 \quad$ Australia-New Zealand Free Trade Area

1983 Becomes Australia-New Zealand Closer Economic Relations Trade Agreement

Arab Common Market* (ARABCM)

1965 Egypt, Iraq, Jordan, Lebanon, Libya, Mauritania, Syria

Automobile Products Trade Agreement (Auto Pact)

1965 Canada, the United States

U.K.-Ireland Free Trade Area*

1966 . United Kingdom, Ireland

Communauté Economique de l'Afrique de l'Oest* (CEAO)

1959 Customs Unions of Western African States predecessor.

1966 Burkina Faso, Côte d'Ivoire, Mali, Mauritania, Niger, Senegal

1984 Benin

Customs and Economic Union of Central Africa* (UDEAC)

1962 Equatorial Customs Union predecessor.

1966 Cameroon, Central African Republic, Chad, Congo, Gabon

1985 Equatorial Guinea

East African Community (EAC)

$1967 \quad$ Kenya, Tanzania, Uganda

$1977 \quad$ Collapsed

Association of Southeast Asian Nations ${ }^{+}$(ASEAN)

1967 Indonesia, Malaysia, Philippines, Singapore, Thailand

1977 Becomes a trade preferences association.

$1984 \quad$ Brunei

Andean Pact* (ANDEAN)

1969 Bolivia, Chile, Colombia, Ecuador, Peru, Venezuela

$1976 \quad$ Chile exits

$1988 \quad$ Andean Group ${ }^{* *}$ formed with all original members.

Caribbean Community and Common Market** (CARICOM)

1968 Caribbean Free Trade Assocation (CARIFTA) predecessor; Antigua and Barbuda, Barbados, Guyana, and Trinidad and Tobago.

1973 Barbados, Guyana, Jamaica, and Trinidad and Tobago

1974 Antigua and Barbuda, Belize, Dominica, Grenada, Montserrat, St. Kitts-Nevis, St. Lucia,

1983 Bahamas

Mano River Union*** (MRU)

1973 Liberia, Sierra Leone

$1980 \quad$ Guinea

Economic Community of Western African States* (ECOWAS)

1975 Benin, Burkina Faso, Cape Verde, Côte d'Ivoire, The Gambia, Ghana, Guinea, Guinea-

Bissau, Liberia, Mali, Mauritania, Niger, Nigeria, Senegal, Sierra Leone, Togo 


\section{Economic Community of the Countries of the Great Lakes* (CEPGL)}

1976 Burundi, Rwanda, Zaire

Bangkok Agreement ${ }^{+}$

1976 Bangladesh, India, Laos, Philippines, South Korea, Sri Lanka, Thailand

Southern African Development Coordination Conference (SADCC)

1980 Angola, Botswana, Mozambique, Tanzania, Zambia, Zimbabwe, Lesotho, Malawi, Swaziland 1990 Namibia

Communauté Economique des Etats de l'Afrique Centrales** (CEEAC)

1981 Burundi, Cameroon, Central African Republic, Chad, Congo, Equatorial Guinea, Gabon, Rwanda, Sao Tome and Principe, Zaire

Organization of Eastern Caribbean States*** (OECS)

1981 Antigua and Barbuda, Dominica, Grenada, Montserrat, St. Kitts-Nevis, St. Lucia,

St. Vincent and Grenadines, British Virgin Islands

Gulf Cooperation Council ${ }^{+}$(GCC)

1983 Bahrain, Kuwait, Oman, Qatar, Saudi Arabia, United Arab Emirates

Preferential Trade Area for Eastern and Southern African States ${ }^{+}$(PTA)

1984 Angola, Burundi, Comoros, Djibouti, Ethiopia, Kenya, Lesotho, Malawi, Mozambique, Mauritius, Rwanda, Somalia, Sudan, Swaziland, Uganda, Tanzania, Zambia, Zimbabwe

Caribbean Basin Economic Recovery Act $^{3}$

1984 Antigua and Barbuda, Aruba, Bahamas, Barbados, Belize, Costa Rica, Dominica, Dominican Republic, El Salvador, Grenada, Guatemala, Guyana, Haiti, Honduras, Jamaica, Montserrat, Netherlands Antilles, Nicaragua, Panama, St. Kitts and Nevis, St. Lucia, St. Vincent and the Grenadines, Trinidad and Tobago, British Virgin Islands

United States-Israel Free Trade Area Agreement*

1985 United States, Israel

South Asian Association for Regional Cooperation ${ }^{4}$ (SAARC)

1985 Bangladesh, Bhutan, India, Maldives, Nepal, Pakistan, Sri Lanka

Canada-US Free Trade Agreement* (CUSFTA)

1989 Canada, the United States

Arab Maghreb Union** (AMU)

1989 Algeria, Libya, Mauritania, Morocco, Tunisia

Sources: Adapted from de la Torre and Kelly (1992), El-Agraa (1994), Lawrence (1996), Nadal de Simone (1995), Whalley (1991), Whalley and Hamilton (1997), WTO (1995).

1 Year agreement went into effect. Typically the agreement is signed a year or two prior.

2 There were two Yaoundé conventions and three Lomé conventions through 1989, indicated by YI, YII, LI, LII, and LIII. The conventions granted non-reciprocal access to the EU market.

${ }^{3}$ Grants non-reciprocal access to the U.S.

4 Became a trade preferences association in 1991.

$+, *, * *, * * *$ Trade preferences association, free trade area, customs union, and common market, respectively. 
No. 93-101 Gordon M.'Phillips, and Robert J. Weiner

"Information and Normal Backwardation as Determinants of Trading Performance: Evidence from the North-Sea Oil Forward Market." 1994. The Economic Journal.

No. 93-102 Stephen R. Goldberg and Frank L. Heflin

"The Association Between the Level of International Diversification and Risk."

No. 93-103 John A. Carlson

"Risk Aversion, Foreign Exchange Speculation and Gambler's Ruin."

No. 93-104 John A. Carlson, Aasim M. Husain, and Jeffrey A. Zimmerman

"Penalties and Exclusion in the Rescheduling and Forgiveness of International Loans."

No. 93-105 Kent D. Miller

"Industry and Country Effects on Manager's Perceptions of Environmental Uncertainties."

1993. Journal of International Business Studies, 24: 693-714.

No. 93-106 Stephen R. Goldberg and Joseph H. Godwin

"Foreign Currency Translation Under Two Cases-Integrated and Isolated Economies."

No. 93-107 Kent D. Miller

"A Comparison of Managers' Uncertainty Perceptions and Country Risk Indices."

No. 93-108 Jon D. Haveman

"The Effect of Trade Induced Displacement on Unemployment and Wages."

No. 93-109 Jon D. Haveman

"Some Welfare Effects of Dynamic Customs Union Formation."

No. 93-110 John A. Carlson and Insook Kim

"Central Banks' Expected Profits From Intervention."

No. 94-001 Casper G. De Vries, Phillip A. Stork, and Kees G. Koedijk

"Between Realignments and Intervention: The Belgian Franc in the European Monetary System."

No. 94-002 Casper G. de Vries and K. U. Leuven

"Stylized Facts of Nominal Exchange Rate Returns."

No. 94-003 Kent D. Miller

"Operational Flexibility Responses to Environmental Uncertainties."

No. 94-004 Kent D. Miller

"Economic Exposure and Integrated Risk Management."

No. 94-005 Kent D. Miller

"Diversification Responses to Environmental Uncertainties."

No. 94-006 John M. Hannon, Ing-Chung Huang, and Bih-Shiaw Jaw

"International Human Resource Strategy and Its Determinants: The Case of Multinationals and Their Subsidiaries in Taiwan."

No. 94-007 John M. Hannon, Ing-Chung Huang, and Bih-Shiaw Jaw

"International Human Resource Strategy and Control: The Case of Multinationals and Their

Subsidiaries." 
No. 94-008

No. 94-009

No. 94-010

No. 94-011

No. 94-012

No. 94-013

No. 94-014

No. 94-015

No. 94-016

No. 94-017

No. 94-018

No. 94-019

No. 94-020

No. 94-021

No. 94-022

No. 95-001

No. 95-002

No. 95-003
John M. Hannon and Yoko Sano

"Customer-Driven Human Resource Policies and Practices in Japan."

John A. Carlson and Insook Kim

"Leaning Against the Wind: Do Central Banks Necessarily Lose?"

John A. Carlson and David W. Schodt

"Beyond the Lecture: Case Teaching and the Learning of Economic Theory."

Alok R. Chaturvedi, Hemant K. Jain, and Derek L. Nazareth

"Key Information Systems Management Issues in Developing Countries: Differences in the Indian and US Contexts."

Jon Haveman,

"The Influence of Changing Trade Patterns on Displacements of Labor."

Stephen Goldberg, Charles A. Tritschler, and Joseph H. Godwin

"Financial Reporting for Foreign Exchange Derivatives."

Charles Noussair, Charles Plott, and Raymond Riezman

"Una investigacion experimental sobre la estructura del comercia interncional (Spanish Version)."

Translated: “An Experimental Investigation About the Structure of International Commerce."

Marie Thursby and Richard Jensen

"Patent Races, Product Standards, and International Competition."

Kent D. Miller and Jeffrey J. Reuer

"Firm Strategy and Economic Exposure to Foreign Exchange Rate Movements."

John Hannon and Yoko Sano

"The Determinants of Corporate Attractiveness in Japan."

John Hannon, Ing-Chung Huang, and Cheng-Chen Lin

"The Mediating Effect of Pre/Post Assignment Acitivities on the Quality of Work Life of Expatriates:

Evidence for Managers in the P.R.C."

John Hannon, Ing-Chung Huang, and Cheng-Chen Lin

"The Mediating Effects of Organization Commitment and Job Involvement on the Relationship Between Quality of Work Life and Customer Service Attitudes."

John A. Carlson and Marc Surchat

"A Model for Filter-Rule Gains in Foreign Exchange Markets."

Ch.N. Noussair, Ch.R. Plott, and R. Riezman

"The Principles of Exchange Rate Determination in an International Finance Experiment."

Stephen R. Goldberg, Joseph H. Godwin, Myung-Sun Kim, and Charles A. Tritschler

"On The Determinants of Corporate Hedging With Financial Derivatives."

Timothy B. Folta

"Sovereignty Conditions and Governance Modes: An Option Theory Approach."

John A. Carlson and Dong-Geun Han

"Monetary Coordination, Fixed Exchange Rates and Noisy Markets."

Jon D. Haveman

“Can Barriers to Trade Make a Differential?" 
No. 95-004 Kent D. Miller and Jeffrey J. Reuer

“Asymmetric Corporate Exposures to Foreign Exchange Rates."

No. 95-005 Gerald J. Lynch and Bradley T. Ewing

"Money Growth Variability and the Term Structure of Interest Rates in Japan."

No. 95-006 Nicholas C. Petruzzi and Maqbool Dada

"Inventory and Pricing in Global Operations: Learning from Observed Demand."

No. 95-007 Kala Krishna and Marie Thursby

"Whither Flat Panel Displays?"

No. 96-001 Thomas Brush, Catherine Maritan, and Aneel Karnani

"Managing a Network of Plants Within Multinational Firms."

No. 96-002 John J. McConnell, Heidi J. Dybevik, David Haushalter, and Erik Lie

"A Survey on Domestic and International Stock Exchange Listings with Implications for Markets and Managers."

No. 96-003 Kala Krishna, Suddhasatwa Roy, and Marie Thursby

"Implementing Market Access."

No. 96-004 Jon Haveman, David Hammels

"Trade Creation and Trade Diversion: New Empirical Results."

No. 96-005 Riki Takeuchi, John M. Hannon

"Antecedents of Expatriate Spouse Adjustments: An Analysis of Japanese Spouses in the United States."

No. 96-006 Bih-Shiaw Jaw, John M. Hannon

"Determinants of International and Intercultural Human Resource Control: The Case Of Taiwanese

Subsidiaries in the People's Republic of China."

No. 96-007 John M. Hannon, Riki Takeuchi

"Adjustment and Job Satisfaction as Antecedents of Intent to Stay: The Case of Japanese Expatriates in the United States."

No. 96-008 John M. Hannon

"Using International Human Resource Management to Inform the Business Intelligence Function."

No. 96-009 Jeffrey J. Reuer, Kent D. Miller

"Agency Costs and the Performance Implications of International Joint Venture Internalization."

No. 96-010 Neven Valev

"International Lending by U.S. Banks."

No. 96-011 Kala Krishna, Marie Thursby, and Suddhasatwa Roy

"Implementing Market Access." (revised)

No. 96-012 Jon D. Haveman

"The Effect of Trade Induced Displacement on Unemployment and Wages."

No. 96-013 Robert A. Buckle and John A. Carlson

"Inflation and Asymmetric Price Adjustment."

No. 97-001 Jeffrey J. Reuer

"Shareholder Wealth Effects of Joint Venture Termination: A Transaction Cost Analysis."

No. 97-002 Jon Haveman and David Hummels

"What Can We Learn from Bilateral Trade? Gravity and Beyond." 
No. 97-003 Douglas Bowman, John U. Farley, and David C. Schmittlein

"Cross-National Empirical Generalization of a Supplier Selection and Usage Model for Foreign

Exchange Services."

No. 97-004 Kent D. Miller

"Measurement of Perceived Environmental Uncertainties: Response and Extension."

No. 97-005 John A. Carlson, C. O. Osler

"Rational Speculators and Exchange Rate Volatility."

No. 97-006 Marie Thursby, Kala Krishna, and Suddhasatwa Roy

"Procompetitive Market Access," Forthcoming, Business and Economics for the $21^{\text {st }}$ Century, Vol. 1.

No. 97-007 John A. Carlson

"Currency Boards, Expectations and Inflation Persistence."

No. 97-008 Jon Haveman, Usha C. Nair, and Jerry G. Thursby

"The Effects of Protection on the Pattern of Trade: A Disaggregated Analysis," Forthcoming, Business and Economics for the $21^{\text {st }}$ Century, Vol. 1.

No. 97-009 George Horwich

"Economic Lessons of the Kobe Earthquake."

No. 98-001 John J. McConnell, Kenneth A. Carow, and Gayle R. Erwin

"Financing Publicly Traded U.S. Corporations in Public and Private Security Markets, 1970-1997:

Where, How, How Much, With What, When, and Why."

No. 98-002 Timothy N. Cason, Tatsuyoshi Saijo, and Takehiko Yamato

"Voluntary Participation and Spite in Public Good Provision Experiments: An International

Comparison."

No. 98-003 Jon D. Haveman, Janet S. Netz, and Vivian Lei

"International Integration and Growth: A Survey and Empirical Investigation."

No. 98-004 Keith V. Smith, Nabil T. Khoury, and Peter I. MacKay

"Comparing Working Capital Practices in Canada, the United States, and Australia: A Note."

No. 98-005 John A. Carlson and Neven T. Valev

"Expectations Formation and Inflation Persistence."

No. 98-006 John A. Carlson and Carol L. Osler

"Determinants of Currency Risk Premiums."

No. 98-007 Jon D. Haveman, Usha Nair-Reichert, and Jerry Thursby

"Trade Reduction, Diversion and Compression: Empirical Regularities in the Effect of Protective Measures."

No. 98-008 Kale Krishna, Suddhasatwa Roy, and Marie Thursby

"Can Subsidies for MARs be Procompetitive?" 